\title{
SECTORAL EFFECTS OF INTELLECTUAL CAPITAL ON MALAYSIAN SME BUSINESS PERFORMANCE
}

\author{
Salwa Muda ${ }^{1}$ and Mara Ridhuan Che Abdul Rahman ${ }^{2}$ \\ ${ }^{1}$ Faculty of Accountancy, \\ Universiti Teknologi MARA, Seremban Campus, Malaysia \\ E-mail: salwa542@uitm.edu.my \\ ${ }^{2}$ Faculty of Economics and Management, \\ University Kebangsaan Malaysia, Malaysia \\ E-mail: mara@ukm.my
}

\begin{abstract}
This paper seeks to estimate and analyze the influence of intellectual capital elements on firm performance on Malaysian SMEs of two sectors, service and manufacturing. The research framework proposes relationships between intellectual capital elements; human capital, structural capital and relational capital and performance. Studies on examining the effects of intellectual capital on performance are growing, however, little is known about how the effects of intellectual capital on SMEs performance differs in different sectors. Questionnaires were delivered to managers and CEOs of SMEs as key informants of the firms to gather the data. A total of 153 usable data from both sectors were analyzed using the PLS-SEM technique through the measurement model, structural model and multigroup analysis (MGA). For the direct relationship, only the effects of human capital (HC) and relational capital on performance show significant results for the full and service sample. Meanwhile, human capital (HC) and structural capital (SC) were found to have significant effects on the manufacturing sector. The multi-group analysis further indicates that the relationship between relational capital and performance differs significantly and was stronger for the service sector.
\end{abstract}

Keywords: intellectual capital, business performance, SMEs, service sector, manufacturing sector.

$\underline{\text { ARTICLE INFO }}$

Article History:

Received: 25 July 2019

Accepted: 29 October 2019

Published: 31 December 2019 


\section{INTRODUCTION}

The emergence of SMEs in Malaysia took place after the Asian financial crisis in 1997-1998. The global economic turmoil during the periods affected the Malaysian economy where foreign investors ran away to other countries that offered profitable options (Arif, 2007). Since then, the Malaysian government took steps forward by building on new local economic engines called SMEs. This new engine was acknowledged as an income stabiliser in the presence of an economic slowdown of large companies. It then led to the plummeting of unemployment and poverty of the people. The literatures reveals that SMEs embed intellectual capital (IC) in ensuring their economic resilience and competencies in the epoch of globalisation and technological rapid changes (Cohen \& Kaimenakis, 2007; Kianto, Hurmelinna-laukkanen \& Ritala, 2010; Khalique \& Pablos, 2015).

Considerable number of researchers from other countries reveal the positive effects of IC on firm performance (Cohen \& Kaimenakis, 2007; Marzo \& Scarpino, 2016; Morariu, 2014; Komnenic \& Pokrajcic, 2012). However, the focus of the researches was skewed towards large firms in developed countries and there is still an unclear relationship between IC and SME performance which warrant further studies. In line with this argument, the extent to which IC management practices is associated with business performance also remains unclear. This issue is not trivial as the SMECORP (2012) reported that $42 \%$ of micro-sized manufacturing SMEs that were formed in 2000 ceased their businesses in 2005. The failure among Malaysian SMEs was reported at 33\% in 2009 while in 2015 it was at $27.1 \%$ (SMECORP, 2016). It is believed that the failure rate to continue their operation can be partly explained from the IC perspective. The first objective of this study therefore was to investigate the IC practice and its relationship with business performance of Malaysian SMEs. Despite the growing numbers, little is known about how the effects of IC practices on business performance differs in the different main sectors; service and manufacturing. Differentiating the firms into service and manufacturing would provide deeper and useful insights on which IC dimensions are perceived to be more important in the specific sectors. It is noted in previous studies that each sector brings different uniqueness in relation to the IC model which eventually give different relationships with their business performance (Kianto, Laukkanen \& Ritala, 2010; St. Pierre \& Audette, 
2011). Therefore, the second objective of this study was to examine the sectoral effect of intellectual capital and business performance.

\section{LITERATURE REVIEW}

\section{Macro Performance of Malaysia SMEs: An Overview}

The Malaysian economy has changed from depending on the agricultural sector that highly relied on rubber and tin in the 1960 s to an industrialised country (Economic Planning Unit, 2013). The execution of the NEP (1971-1990), Third Malaysia Plan (1976-1980), Fourth Malaysia Plan (1981-1985) and Fifth Malaysia Plan (1986-1990) provided opportunities for SMEs to grow, develop and contribute to the nation's economy. The establishment witnessed the government's commitment and concern in helping entrepreneurs by spending huge amounts of money as well as providing business support for Malay entrepreneurs (Yusoff \& Zainol, 2014). However, the Asian financial crisis that struck many Asian countries in 1997-1998 led to the global economic slowdown (Economic Planning Unit, 2013). This crisis left Malaysia with a lesson not to heavily rely on the foreign direct investment (FDI) to stimulate the economy (Aris, 2007). After the crisis, SMEs were recognised as major tools in generating domestic-led investments, stimulating economic expansion and increasing the job market for the country. The role of SMEs in the Malaysian economic development helps the country to minimise the worse scenarios due to the financial crisis, which include high rate of unemployment and poverty (Economic Planning Unit, 2013).

To express the commitment to support SMEs, the Malaysian government undertook various incentives through the establishment of a few policies. In 2004, the National SME Development Council (NSDC) was established with the aim to promote the development of Malaysian SMEs through coordinated and comprehensive measures. In June 2008, a new agency named SME Corporation Malaysia (SMECORP) was established to perform roles in formulating policies and coordinating programmes for SMEs. In 2010, the government introduced the SME Masterplan (20122020) as a recognition towards the contribution of SMEs in transforming the nation's economy to a higher level of achievement. 
The SME Annual Report 2017/2018 reports that SMEs contributed $31.1 \%$ to national GDP and also recorded 7.2\% GDP growth in 2017 (2016:5.2\%) which outperformed the national GDP growth (5.9\%). In another official report, the Malaysia Department of Statistics revealed that SMEs GDP accounted for RM435.1 billion in 2017, contributed $66 \%$ of Malaysia total employment and 7.9\% (RM12.3 billion) of total Malaysia export value. Given the SME Masterplan 2012-2020 aiming for $41 \%$ of GDP, $62 \%$ of employment and $25 \%$ of exports in 2020 , it is crucial for SMEs to put more effort into improving themselves to achieve it. To date, there are 920,624 SMEs in Malaysia expected to join these efforts. It is believed that, incorporating IC into management practice would stimulate SME performance in the technological age (Ngah \& Ibrahim, 2009).

\section{IC Practices in SMEs}

IC is defined as the possession of knowledge, applied experience, organisational technology, customer relationships, and professional skills that provides firms with a competitive edge in the market (Edvinsson, 1997). Bontis (1998) refers it as the pursuit of effective use of knowledge that is embedded in human intellect, organizational routines and market relationships. The common acceptance of IC categories consists of human capital (HC), structural capital (SC) and relational capital (RC) as proposed by some prominent authors, for example Sveiby (1997), Roos et al. (1997), Bontis (1998), Mayo (2000) and Petty and Guthrie (2000).

$\mathrm{HC}$ refers to the individual abilities, knowledge, know-how, talent and experience of individuals of the firms namely managers and employees (Edvinsson \& Malone, 1999). SC refers to all the non-human storehouses of knowledge in organizations which includes databases, organizational charts, process, routines and anything that gives value to firms (Bontis, 1998). RC is the knowledge embodied in the networks between firms and external stakeholders such as customers, trade association, suppliers and the government that can influence business performance (Bontis, 1998). The value created from the relationships with customers, which is supported by good interaction of human capital and structural capital is able to provide firms with better performance. 
SMEs possess some exclusive characteristics that distinguishes them from larger firms. It is posited that SMEs operate with many limitations including financial scarcity, skilful employees and in-house formal structures and systems (Saleh \& Ndubisi, 2006; Daou et al., 2014; Zainol \& Zainol Ariffin, 2013). This in turn hinders SMEs from reaping the potential benefits of IC (Hilmi et al., 2011; Omar, Arokiasamy \& Ismail, 2009). However, on the positive side, the small size provides them with advantages in managing the knowledge resources that flow through individuals, internal structure and external relationships (Coyte et al., 2012; Desouza \& Awazu, 2006). It is inevitably important for SMEs to fully utilise the knowledge resources they possess as a way to counterbalance their limitations (Cohen et al., 2014; Desouza \& Awazu, 2006).

Desouza and Awazu (2006) contend that compared to large firms, the knowledge transfer in SMEs occurs naturally from formal and informal socialisation. The formal way of explicit knowledge transfer is done with the existence of ICT systems and automated mechanisms. In the absence of proper structure like SMEs, the formal transfer of tacit knowledge that normally resides in the minds of the owner cannot be done. Thus it is important for the employees to informally socialise in an organisation to gain common knowledge. The informal transfer is likely workable in SMEs due to the close relationships between the owners and the employees and among employees in the firms. The depth and breadth of tacit knowledge apparently is important to hinder the firms from the loss of knowledge should any of the employees leave. The tacit knowledge that resides in the owners will help SMEs to continue their operations and at the same time new employees will be trained with common knowledge instantly (Desouza \& Awazu, 2006). Therefore, it is important for the SMEs to transfer the tacit knowledge into explicit, recordable and accessible assets to refrain from the loss of knowledge and improve competitiveness simultaneously. However, the limited documented knowledge among SMEs such as patents, technologies, ICT systems and other automated mechanisms are due to some issues including the high costs to be incurred and complexities in getting the structures to be fixed in the firms (Huggins \& Weir, 2012; Thorpe et al., 2005).

In the aspect of external relationships, SMEs are argued to still have close relationships with customers despite their lack of resources such as 
limited marketing and distribution channel expenses. For instance, Desouza and Awazu (2006) reported that SMEs reap the advantages on the expenses incurred by larger firms by operating within the same areas of larger firms. Previous market research that have been conducted by the larger firms regarding the suitability of the area as the point of customers' attraction provide SMEs with the exploitation of external sources of knowledge. Moreover, the effort of SMEs in understanding the need of their different groups of customers such as university students through part-time job offerings and discounted prices brings them closer to the communities (Desouza \& Awazu, 2006).

There is little that is known about how the effects of IC practices on performance differs in different main sectors; service and manufacturing. Distinguishing the firms into service and manufacturing, can provide useful insights on which IC dimensions are perceived to be more important in a specific industry or sector (Kianto, Laukkanen \& Ritala, 2010). In analyzing the influence of IC on firm performance, there is a need to explore how the relationships vary from business to business (St. Pierre \& Audette, 2011). The service sector is characterized as establishing a close interaction with customers and other stakeholders, the combination of knowledge into sets of useful systems, and the utilization of ICT in their daily routines (Kianto et al., 2010). Firms in the service sector rely heavily on the knowledge and skills of the individuals in the firm due to the tasks that are based on the consultancy approach in attracting customers and other stakeholders. In contrast, firms in the manufacturing sector are not necessarily associated with activities requiring a comprehensive and high level of knowledge which might limit the focus on RC (St. Pierre \& Audette, 2011). Due to the reliance on high level of technologies and automated systems in producing the output, manufacturing firms value SC over RC. Though studies have been carried out in examining the relationships between IC and performance, there is insufficient empirical research investigating the relationship in SMEs and specifically in different sectors.

\section{Previous Studies of IC Practices and Business Performance of SMEs}

The effect of IC practices in improving large firm performance is not new. It has attracted many researchers from various countries. A majority 
of studies applied the VAIC model by Pulic (2003) for example Goh (2005) and Wei and Ting (2009). Nevertheless, the application of the VAIC model has been criticised for a few reasons. Ståhle et al. (2011) pointed that the variables used are purely financial parameters and do not consist of actual content that refers to IC for example customer satisfaction, skills of employees, experience, training and motivation etc.

There are considerable numbers of previous studies that show evidence of the positive effects of intellectual capital and business performances in SMEs (e.g Cohen \& Kaimenakis, 2007; Tovstiga \& Tulugurova, 2007; Ngah \& Ibrahim, 2009; Kianto et al., 2010; St. Pierre \& Audet, 2011; Steenkamp \& Kashyap, 2010; Khalique \& Pablos, 2015). Overall, the studies conclude that SMEs with IC practices enable them to obtain superior performance. Nonetheless, it seems that the effect of intellectual capital on business performance varies according to its categories.

Tovstiga and Tulugurova (2007) investigated 20 innovative Russian SMEs and the findings suggest that internal factors especially $\mathrm{HC}$ that includes competency, attitude and intellectual agility, are the more prevalent factors in determining SME performance compared to other IC categories. Similarly, Kianto et al. (2010) studied the effects of SC on services and nonservices' SME performance and discovered that SC insignificantly affects SME performance compared to HC. In another preliminary study, Ngah and Ibrahim (2009) interviewed 12 respondents such as owners, managers and executives, and found that IC affects product and service innovation as well as SME performance. The study concluded that the size of SMEs leads to the close connection and creativities among employees, between employees and external stakeholders, and adequate technological support, which encourage SMEs to embark in innovative activities that will fulfil the needs of customers and in turn enhance their performance.

Steenkamp and Kashyap (2010) studied the perception of SME managers in New Zealand about the importance and contribution of IC practices to their businesses. $\mathrm{RC}$ and $\mathrm{HC}$ were found to have larger impacts on SME businesses. The top ten items of IC that were perceived as the most important are customer satisfaction, customer loyalty, product reputation, corporate reputation, employee know-how, employee loyalty, relationships with suppliers, employees' job satisfaction, management systems and 
training of employees. Similarly, Daou et al. (2014) provided additional evidence about the important role of RC from the perception of $445 \mathrm{SME}$ managers from three different clusters in Mexico. The study reported that the satisfaction of clients, SME images, product reputation and relationships with stakeholders appear to be the most important elements of IC, which are consistent with other studies in the context of emerging economies.

In a more recent empirical study, Khalique and Pablos (2015) investigated the relationship between IC and performance by applying the extended IC model ranging from human capital, structural capital, customer capital, social capital, technological capital and spiritual capital. The administered questionnaires were delivered to the employees of 115 SMEs listed in the Electrical and Electronics Association of Malaysia (TEEAM) dan Federation of Malaysian Manufacturers (FMM) database. The findings revealed that $\mathrm{HC}$ and $\mathrm{SC}$ provide firms with a significant contribution to performance. In contrast, the study found that customer capital and social capital were insignificantly contributing towards SME performance. The researchers believed that the insignificant roles of the customer capital and social capital on firm performance are reasoned by some SMEs that only rely on individual knowledge and skills of their employees in improving their value creation, but do not put a high effort in establishing the knowledge sharing and transfer among employees as well as with the external stakeholders.

\section{UNDERLYING THEORY AND HYPOTHESES DEVELOPMENT}

The Resource-based View (RBV) suggests that a firm's resources have the potential to offer firms with a competitive advantage and superior performance. The heterogeneity of resources bundles and internal capabilities distinguish the firms from their competitors in a strategic point of view (Barney, 1991). In line with the RBV, IC comprises intangible resources that are embedded with knowledge that can be used by firms to achieve predetermined objectives and creating value through the combination of the resources (Cohen \& Kaimenakis, 2007). 
The literature has established that $\mathrm{HC}$ is crucial in this knowledgebased economy (Daou et al., 2014; Kamukama, 2013). Sveiby (1997) argued that the people are the only profit generators of the firms. Employees gain their importance as drivers of firm value through increasingly providing firms with positive individual contributions from time to time. SMEs with a small number of employees form close connections among them, thus serve the platform for better knowledge management, innovation activities and building association with stakeholders for enhanced performance (Coyte et al., 2012; Desouza \& Awazu, 2006; Ngah \& Ibrahim, 2009). Many empirical studies have found direct or indirect positive impacts of $\mathrm{HC}$ on firm performance, specifically the higher contribution of HC in SMEs (Cohen \& Kaimenakis, 2007; Khalique \& Pablos, 2015; Tovstiga \& Tulugurova, 2007). Accordingly, it is hypothesised that:

H1: $\mathrm{HC}$ is positively associated with firm performance.

$\mathrm{SC}$ can assist the role of $\mathrm{HC}$ in enhancing firm performance (Bollen, et al., 2005; Bontis, 1998). Belkoui (2003) proposed that SC is the only element that can show how good the firms utilise their resources through the creation of intellectual property, which represents the available output of the human intelligence. Importantly, SC enables the sharing of knowledge from tacit to explicit through the availability of good processes, systems and culture, hence providing opportunities for firm performance (Bontis, 1998). Kamaluddin and Abdul Rahman (2009) examined Malaysian public listed firms and revealed that SC significantly predicted firm effectiveness measured by profitability, quality, sales growth, employee satisfaction and overall performance. Likewise, Abdullah and Sofian (2012) indicated that $\mathrm{SC}$ is positively associated with performance of public firms in Malaysian PLCs. Therefore, the following hypothesis is posited:

H2: SC is positively associated with firm performance.

The close connection with external parties offers a broad range of advantages including better cost allocation, enhancing innovation, improving learning, networks and business performance (Cabrita \& Bontis, 2008; Wang et al., 2014). Peltier and Naidu (2012) posited that SMEs have a tendency to appreciate the relationships with customers, suppliers and financial institutions whenever they need advice regarding the strategies 
they need to pursue for better achievement. A study of Sharabati et al. (2010) on pharmaceutical firms in Jordan suggested a positive significant impact of RC on firm performance. St-Pierre and Audet (2011) found a positive significant effect of RC on firms that pursue the prospector strategy. The focus of firms with a prospector strategy is to penetrate new markets through product innovations, therefore it is important to have a close connection with customers in order to gain knowledge on the potential market. In another study, Wang et al. (2014) found a significant influence of RC on operational and financial performance of high-technology firms in China. Given the importance of relational capital to firm performance, it is therefore hypothesised that:

H3: RC is positively associated with firm performance.

Due to differences in the features of the service and manufacturing sectors, the effect of the $\mathrm{HC}, \mathrm{SC}$ and $\mathrm{RC}$ on firm performance is hypothesized to be different. In their study, Kianto et al. (2010) found that the effect of $\mathrm{HC}$ was stronger for firms in service sector as compared to manufacturing firms. The findings of the study by Bontis, Chau and Keow (2000) indicate the importance of SC in manufacturing firms as opposed to service firms. Accordingly, it is hypothesized that:

H4: Effects of HC, SC and RC on firm performance will be significantly different among SMEs according to sectors

\section{METHODOLOGY}

\section{Sample and Data}

The Proportionately stratified random sampling was applied as the sampling method. The lists of SMEs were derived from the Malaysian SME Community Directory comprising of samples from the manufacturing sector such as food and beverages, chemicals and electrical and services sector comprising industries in education, professional and education. Prior to the actual survey, a pilot survey was conducted on 30 non-sample key informants to identify whether the respondents understood and interpreted the questions and instructions in a uniform manner (Sekaran \& Bougie, 
2010). The results of the reliability test for the pilot survey indicated that the Cronbach Alpha coefficient size is between 0.7 and 0.8 for each construct under the study, thus the strength of association between measures were considered as good (Hair et al., 2007). This study employed a survey method using close-ended postal questionnaire. A total of 1,000 questionnaires were addressed to the CEOs and managers of the SMEs. A total of 153 returned questionnaires were applicable for data analysis, giving a response rate of $15.3 \%$. The Partial-Least Square Structural Equation Modelling (PLS-SEM) technique was used to analyse data.

\section{Variables Measurement}

IC management practices was subdivided into three elements namely $\mathrm{HC}, \mathrm{SC}$ and RC. Each category was operationalized with 12 items, making the total items 36 . The measurement for intellectual capital was adapted from Bontis (1998), Kamukama (2013), Khalique and Pablos (2015), Sharabati et al. (2010) and Tovstiga and Tulugurova (2007). The measurement for business performance was divided by two which was adapted from Wang et al. (2014). The first part measured financial performance such as return on assets, return on sales, profit growth and sales growth. The second part refers to non-financial performance such as customer satisfaction, productivity, quality development, cost management and responsiveness (see appendix A). A five-point Likert scale was adopted for all item scales of IC practices and business performance, anchored on a five point scale, ranging from 1strongly disagree to 5- strongly agree. Respondents rated their agreement on their IC practices in the company and business performance compared to their competitors.

\section{RESULTS}

\section{The Respondent's Profiles}

Table 1 demonstrates the demographic details of SMEs sampled for this study. The respondents comprised of 80 SMEs in manufacturing and 73 in the service sector. The SMEs were grouped into small size (54.2\%) and medium size (45.8\%). For turnover, 30.7\% represents SMEs with the range between RM300,000 to RM3,000,000, 30.7\% for turnover between RM3,000,000 to RM15,000,000, 22.9\% for turnover between 
RM15,000,000 to RM20,000,000 while another $15.7 \%$ SMEs recorded turnover between RM20,000,000 to RM50,000,000. Data showed that most of the SMEs have been operating in the industry for more than 15 years (56.2\%), followed by 11 to 15 years (22.95), 6 to 10 years $(11.8 \%)$ and 1 to 5 years $(9.2 \%)$. The sample SMEs obtained in this study was considered to have sufficient maturity in terms of turnover and years of operation, thus they are acceptably representative to fit the objectives of the study.

Table 1: Demographic Profiles

\begin{tabular}{llcc}
\hline \multirow{2}{*}{ Characteristics } & \multicolumn{1}{c}{ Types } & $\begin{array}{c}\text { Frequencies } \\
(\boldsymbol{n}=\mathbf{1 5 3 )}\end{array}$ & $\begin{array}{c}\text { Percentage } \\
(\mathbf{\%})\end{array}$ \\
\hline \multirow{2}{*}{ Sector } & Manufacturing & 80 & 52.3 \\
& Services & 73 & 47.7 \\
& Total & 153 & 100 \\
\hline Years & 1-5 years & 14 & 9.2 \\
& 6-10 years & 18 & 11.8 \\
& 11-15 years & 35 & 22.9 \\
& More than 15 years & 86 & 56.2 \\
& Total & 153 & 100 \\
\hline Position & CEO & 17 & 11.1 \\
& Manager & 89 & 58.2 \\
& Assistant manager & 47 & 30.7 \\
& Total & 153 & 100 \\
\hline Size & Small & 83 & 54.2 \\
& Medium & 70 & 45.8 \\
& Total & 153 & 100 \\
\hline Turnover & Less than RM300 000 & 0 & 0 \\
& RM300 000-RM3million & 47 & 30.7 \\
& RM3million-RM15million & 47 & 30.7 \\
& RM15million-RM20million & 35 & 22.9 \\
& RM20million-RM50million & 24 & 15.7 \\
& Total & 153 & 100 \\
\hline
\end{tabular}

\section{Hypotheses Testing}

The PLS-SEM approach was used to test all hypothesized relationship in the research model through measurement model assessment, structural model assessment and multigroup analysis (MGA). The reliability and validity of the items and constructs were assessed in the measurement model by obtaining the value for outer loadings, indicator reliability, internal consistency, convergent validity, and discriminant validity of full 
sample and sector samples. To satisfy the measurement model assessment, the indicator loadings and composite reliability (CR) must exceed 0.7, average variance extracted (AVE) to measure convergent validity must be greater than 0.5 and the square root of AVE must be greater than the intercorrelations to achieve discriminant validity (Hair et al., 2017). All constructs in the research model satisfied the requirements for reliability and validity. Table 2 shows the results of measurement model assessment in related to outer loadings for full, service and manufacturing samples. The reliability and validity assessment are indicated in Table 3 . To indicate how well the indicators represent their construct and at the same time differ from the other constructs, discriminant validity was assessed through the Fornel and Larcker criterion (Forner \& Larcker, 1981; Urbach \& Ahlemann, 2010). Discriminant validity is achieved when the square root of AVE exceeds the correlations between the measure and all other measures. The results of discriminant validity of this study confirmed that the Fornell and Larcker's criterion was met.

Table 2: Convergent Validity for Full and Sector Samples

\begin{tabular}{ccccc}
\hline Constructs & Items & \multicolumn{3}{c}{ Loadings } \\
\hline \multirow{3}{*}{ Human Capital $(\mathrm{HC})$} & & Full & Service & Manufacturing \\
& HC1 & 0.848 & 0.832 & 0.861 \\
& HC2 & 0.864 & 0.860 & 0.856 \\
& HC3 & 0.833 & 0.825 & 0.831 \\
& HC4 & 0.841 & 0.853 & 0.822 \\
& HC5 & 0.786 & 0.921 & 0.904 \\
& HC6 & 0.764 & 0.678 & 0.952 \\
& HC7 & 0.678 & 0.865 & 0.877 \\
& HC8 & 0.988 & 0.932 & 0.732 \\
& HC9 & 0.766 & 0.811 & 0.819 \\
& HC10 & 0.687 & 0.699 & 0.925 \\
& HC11 & 0.946 & 0.732 & 0.800 \\
& HC12 & 0.798 & 0.922 & 0.701 \\
\hline Structural capital (SC) & SC1 & 0.821 & 0.800 & 0.859 \\
& SC2 & 0.731 & 0.692 & 0.793 \\
& SC3 & 0.794 & 0.859 & 0.670 \\
SC4 & 0.805 & 0.823 & 0.799 \\
SC5 & 0.809 & 0.8 .37 & 0.735 \\
SC6 & 0.693 & 0.675 & 0.703 \\
SC7 & 0.820 & 0.888 & 0.987
\end{tabular}




\begin{tabular}{ccccc}
\hline Constructs & Items & \multicolumn{3}{c}{ Loadings } \\
\hline SC8 & 0.752 & 0.954 & 0.876 \\
SC9 & 0.920 & 0.900 & 0.811 \\
SC10 & 0.890 & 0.761 & 0.877 \\
& SC11 & 0.769 & 0.919 & 0.815 \\
& SC12 & 0.698 & 0.866 & 0.975 \\
\hline Relational Capital (RC) & RC1 & 0.742 & 0.738 & 0.758 \\
& RC2 & 0.779 & 0.803 & 0.768 \\
& RC3 & 0.796 & 0.831 & 0.760 \\
RC4 & 0.569 & 0.506 & 0.635 \\
& RC5 & 0.787 & 0.796 & 0.760 \\
RC6 & 0.807 & 0.826 & 0.775 \\
RC7 & 0.789 & 0.743 & 0.837 \\
RC8 & 0.768 & 0.714 & 0.829 \\
RC9 & 0.777 & 0.768 & 0.722 \\
RC10 & 0.976 & 0.765 & 0.757 \\
RC11 & 0.872 & 0.874 & 0.784 \\
RC12 & 0.823 & 0.911 & 0.870 \\
\hline P1 & 0.906 & 0.910 & 0.913 \\
P2 & 0.932 & 0.952 & 0.879 \\
P3 & 0.900 & 0.918 & 0.922 \\
P4 & 0.847 & 0.926 & 0.716 \\
P5 & 0.899 & 0.888 & 0.834 \\
P6 & 0.706 & 0.892 & 0.791 \\
P7 & 0.986 & 0.921 & 0.843 \\
P8 & 0.777 & 0.799 & 0.794 \\
P9 & 0.831 & 0.981 & 0.819 \\
\hline & & & &
\end{tabular}

Table 3: Convergent Validity for Sector Samples

\begin{tabular}{lccccccccc}
\hline & \multicolumn{3}{c}{ Full Sample } & \multicolumn{3}{c}{ Service sector } & \multicolumn{3}{c}{ Manufacturing } \\
\hline Constructs & CR & AVE & CA & CR & AVE & CA & CR & AVE & CA \\
HC & 0.910 & 0.717 & 0.868 & 0.907 & 0.710 & 0.864 & 0.907 & 0.710 & 0.865 \\
SC & 0.901 & 0.604 & 0.868 & 0.905 & 0.615 & 0.873 & 0.892 & 0.852 & 0.859 \\
RC & 0.915 & 0.575 & 0.892 & 0.911 & 0.654 & 0.886 & 0.919 & 0.689 & 0.901 \\
PERF & 0.943 & 0.926 & 0.919 & 0.960 & 0.859 & 0.945 & 0.919 & 0.742 & 0.865 \\
\hline
\end{tabular}

Notes: $\mathrm{CR}=$ Composite reliability, $\mathrm{CA}=$ Cronbach's Alpha

Following the satisfactory measurement model, the structural model assessment was conducted to examine the hypothesized relationships between IC and performance. The validity of the structural model was 
assessed using the coefficient of determination $(R)^{2}$ and path coefficients. The $\left(R^{2}\right)$ indicates the amount of variance in dependent variables (performance) that is explained by the independent variables (IC elements). The result obtained for the $R^{2}$ value in this study was $45.3 \%$. The bootstrapping method with a resampling of 1,000 was used to estimate the significance of the path coefficients (Chin, 1998). The path coefficients, t-values and result for hypotheses for each path relationship and for overall and sectorbased models are shown in Table 4 . The bootstrapping results indicated that the H1 (human capital and business performance) was supported in the full sample $(\mathrm{t}-\mathrm{value}=3.102)$, the service sample $(\mathrm{t}$-value $=2.002)$, and the manufacturing sample ( $\mathrm{t}$-value $=2.642$ ). For $\mathrm{H} 2$ (structural capital on business performance), the results indicated the significant effects only in the manufacturing sample $(\mathrm{t}-\mathrm{value}=1.970)$, but do not support the full and service sample. Lastly, H3 (relational capital and business performance) was only supported in full sample $(\mathrm{t}$-value $=3.376)$ and service sector $(5.092)$, while not supported in the manufacturing sample.

Table 4: Result for Direct Relationships for Full Sample and Sector Sample

\begin{tabular}{cccccccccccc}
\hline & \multicolumn{4}{c}{ Full Sample } & \multicolumn{3}{c}{ Service sector } & \multicolumn{3}{c}{ Manufacturing } \\
\hline & Path & PC & t-value & Sig. & PC & t-value & Sig & PC & t-value & Sig. \\
H1 & HC à & 0.272 & $3.102^{*}$ & S & 0.202 & $2.002^{*}$ & S & 0.346 & $2.642^{*}$ & S \\
& $\begin{array}{c}\text { PERF } \\
\text { H2 }\end{array}$ & $\begin{array}{c}\text { SC à } \\
\text { PERF }\end{array}$ & 0.027 & 1.190 & NS & 0.102 & 1.634 & NS & 0.360 & $1.970^{*}$ & S \\
& $\begin{array}{c}\text { PER } \\
\text { H3 }\end{array}$ & $\begin{array}{c}\text { RC à } \\
\text { PERF }\end{array}$ & 0.406 & $3.376^{*}$ & S & 0.561 & $5.092^{*}$ & S & 0.265 & 1.288 & NS \\
\hline
\end{tabular}

${ }^{*} t>1.645$ are significant at $p<0.05$ (one-tailed)

Furthermore, the PLS multi-group analysis was carried out to test the differences between the path coefficients for manufacturing and service sector sub-samples in order to test $\mathrm{H} 4$. The results in Table 5 show that only path coefficients of the effects of RC on performance differed significantly between service and manufacturing sample with $p$-value 0.044 . Hence, the $\mathrm{H} 4$ is partly supported. The path coefficient of service sector $(\beta=0.602)$ was higher than manufacturing sector $(\beta=0.426)$ in which indicates the stronger effect in service sector than manufacturing sector. The relationships between $\mathrm{RC}$ and performance in the service sector was stronger than manufacturing. 
Table 5: Result of Multi-Group Analysis

\begin{tabular}{lcccc}
\hline & Service & Manufacturing & \\
\hline HC -> PERF & 0.202 & 0.346 & 0.799 & NS \\
SC -> PERF & 0.561 & 0.265 & 0.322 & NS \\
RC -> PERF & 0.602 & 0.426 & $0.044^{*}$ & Sig \\
\hline
\end{tabular}

significant at $p<0.05$

\section{DISCUSSION}

The findings show a significant relationship for two paths in the full sample; first the relationship between $\mathrm{HC}$ and business performance and second is the relationship between RC and business performance. However, SC was found to be an insignificant driver for performance of SMEs in the whole data set. The material effects of $\mathrm{HC}$ and $\mathrm{RC}$ practice by SMEs in bringing firms to achieve superior performance is consistent with prior studies of Tovstiga and Tulugurova (2007), Daou et al. (2014), Marzo and Scarpino (2016), Khalique and Pablos (2015). The findings offer evidence that SMEs are relying and emphasizing on the internal employees in the firms and their association with external parties. It can be argued that the small size of the SMEs enables them to build close and effective relationships with their employees which in turn facilitate the transfer of tacit knowledge among them (Coyte, Ricerrri \& Guthrie, 2012). The smaller number of employees compared to large firms may also enable SMEs to invest on $\mathrm{HC}$ on training and motivation programs at a lower cost which eventually increases their productivity. Moreover, the knowledge that is embedded through close relationships with external stakeholders helps SMEs in building reputation and maintaining the connection which in turn enables them to improve customer satisfaction and loyalty.

Nevertheless, the results indicate that SC was not perceived as a significant contributor for SMEs in achieving performance. The findings are coherent with Suraj and Bontis (2012) and St. Pierre and Audette (2011) who found the insignificant role of SC in this regard. Perhaps, it is due to the fact that limited technology, $\mathrm{R} \& \mathrm{D}$, information systems and availability of documentation systems may impede the SMEs to perform. The lack of SC among SMEs may appear to be prevalent in the presence of limited financial resources. Despite the good ideas and knowledge on innovation, 
the lacking in structural resources faced by SMEs will not enable firms to transform the ideas into reality (Huggins \& Weir, 2012).

In order to deepen the study, the overall model was segregated into the service and manufacturing sector and the analysis produced a variety of findings. The findings show that only the path of the $\mathrm{HC}$ was shown as a consistent predictor of business performance across all the sector samples. Other findings show that the relationship between SC and business performance in the services sector was not significant as exhibited in the manufacturing sector. By contrast, the effects of RC on business performance were found to have a significant influence in the service sector but not significant in the manufacturing sector.

It can be inferred that managers perceive the importance of IC elements differently according to the nature of their firm and in which sector the firms are operating. The effects of IC on performance are not uniformly presented by all the sectors. The service sector indicates that the external relationship is stronger for firms in the service sector. The results are in agreement with the characteristic of the service sector that are having close interactions with customers, able to fulfill the demands according to customer requirements and the ability to attend to complaints and feedback from customers in a short period (Kianto et al., 2012; Marzo \& Scarpino, 2016). This is an indication that firms in the service sector focus in investment related to enhancing the association with other parties outside of their firms as a way to achieve competitive advantage and attaining superior performance to stay relevant in the industry especially in a knowledge-driven economy. Manufacturing sector on the other hand is prevalent in SC regards. This is commonly posited in many previous studies as manufacturing sector still predominantly relies on hard-form of IC such as equipment, manufacturing systems, routines SOP, ICT and technological tools to survive.

\section{CONCLUSION}

The results of the study are in line with previous studies which demonstrate that IC is a main contributor to competitive advantage and performance of SMEs particularly in the contribution of $\mathrm{HC}$ and $\mathrm{RC}$ on business performance. Although operating with limited financial resources, 
Malaysian SMEs may still believe that knowledge, skills, qualification an experience of individuals are beneficial for firms and society at large. In relation to $\mathrm{RC}$, the findings suggest that SMEs continuous engagement with external clients such as customers, and the financial providers reap benefits from the knowledge created and transferred between firms and the stakeholders. On the other hand, SC was not perceived as a significant driver for firm performance except in the manufacturing sector. Nevertheless, the insignificance of $\mathrm{SC}$ as a predictor does not imply that SMEs should abandon their investments in it. The focus on the SC might be started with the effort in providing databases and enhancing the process and procedures and later followed by the investment in information systems and $R \& D$ that requires higher costs. A multi-group analysis was conducted to test whether there are significant difference for paths between sample of firms in the service and manufacturing sectors. As a result, the relationship between RC in the service sector significantly differs in the service sector compared to the manufacturing sector. Accordingly, firms in the service sector focus more on enhancing the connection with their clients as most of their job scope requires them to have a direct consultation with clients, while firms in the manufacturing are more product-oriented based. Overall, this study helps to create awareness to managers and policy makers on the importance of IC elements in driving SMEs to attain superior performance in globally challenging economies. The effective implementation of IC practices in SMEs may reduce the possibility of ceasing their operation in the short run. This is evidently shown in this study where the effects of IC practices on performance are centered on established SMEs.

This study has a few limitations. This study is based on cross-sectional data collection. The data were collected at a single point in time which could not capture the development in IC dimensions and performance. A longitudinal study is suggested in future research work in examining the effects of IC on performance to obtain more robust findings. In addition, this study used a questionnaire to gather information from the respondents, however only a small number of responses were received. Future research may consider the adoption interviews to gather as much information as possible regarding their perception on the importance of intellectual capital. 


\section{REFERENCES}

Abdullah, D. F. \& \& Sofian, S. (2012). The relationship between intellectual capital and corporate performance. Procedia - Social and Behavioral Sciences, 40(6), 537-541.

Aris, N. (2007). SMEs : Building blocks for economic growth. Department of Statistics Malaysia.

Barney, J. (1991). Firm resources and sustained competitive advantage. Journal of Management, 17(1), 99-120.

Belkaoui, A. R. (2003). Intellectual capital and firm performance of US multinational firms: A study of the resource-based and. Journal of Intellectual Capital, 4(2), 215-226.

Bollen, L., Vergauwen, P. \& Schnieders, S. (2005). Linking intellectual capital and intellectual property to company performance. Management Decision, 43(9), 1161-1185.

Bontis, N. (1998). Intellectual capital: An exploratory study that develops measures and models. Management Decision, 36(2), 63-76.

Bontis, N., Chua, W., \& Keow, C. (2000). Intellectual capital and business performance in Malaysian industries. Journal of Intellectual Capital, $1,85-100$.

Bontis, N., Dragonetti, N. C., Jacobsen, K., \& Roos, G. (1999). The knowledge toolbox: A Review of the tools available to measure and manage intangible resources. European Management Journal, 17(4), 391-402.

Cabrita, M. do R. \& Bontis, N. (2008). Intellectual capital and business performance in the Portuguese banking industry. International. Journal of Technology Management, 43(1-3), 212-237.

Chin, W. W. (1998). The partial least squares approach to structural equation modeling. In G. A. Marcoulides (Ed.). Modern Methods for Business 
Research (pp. 295-336). Mahwah, New Jersey: Laurence Erlbaum Associates.

Cohen, S., \& Kaimenakis, N. (2007). Intellectual capital and corporate performance in knowledge-intensive SMEs. The Learning Organization, $14,241-262$.

Coyte, R., Ricceri, F., \& Guthrie, J. (2012). The management of knowledge resources in SMEs: An Australian case study. Journal of Knowledge Management, 16(5), 789-807.

Daou, A., Karuranga, E. \& Su, Z. (2014). Towards a better understanding of intellectual capital in Mexican SMEs. Journal of Intellectual Capital, 15(2), 316-332.

Desouza, K. C. \& Awazu, Y. (2006). Knowledge management at SMEs: Five peculiarities. Journal of Knowledge Management, 10(1), 32-43.

Economic Planning Unit. (2013). Economic Development. Malaysia.

Edvinsson, L. \& Malone, M. (1997). Intellectual capital: Realizing your company's true value by finding its hidden brainpower. New York: Harper Collins Publisher Inc

Edvinsson, L. (1997). Developing intellectual capital at Skandia. Long Range Planning, 30(3), 366-373.

Fornell, C., \& Larcker, D. F. (1981). Evaluating structural equation models with unobservable variables and measurement error. Journal of Marketing Research, 18(1), 39-50.

Goh, P. C. (2005). Intellectual capital performance of commercial banks in Malaysia. Journal of Intellectual Capital, 6(3), 385-396.

Hair, J., Hult, T., Ringle, C. \& Sarstedt, M. (2017). A Primer On Partial Least Squares Structural Equation Modeling (PLS-SEM) ( $2^{\text {nd }}$ ed.). London: SAGE Publications. 
Hilmi, M. F., Thurasamy, R., Mustapha, Y \& Pawanchik, S. (2011). Exploring intellectual capital of Malaysian small and medium entrepreneurs. 2011 IEEE Colloquium on Humanities, Science and Engineering, CHUSER 2011, (pp. 626-631).

Huggins, R., \& Weir, M. (2012). Intellectual assets and small knowledgeintensive business service firms. Journal of Small Business and Enterprise Development, 19(1), 92-113.

Kamaluddin, A \& Rahman, R. A. (2009). Enhancing organisation effectiveness through human, relational and structural capital: An empirical analysis. Malaysian Accounting Review, 8(1), 1-17.

Kamukama, N. (2013). Intellectual capital: Company's invisible source of competitive advantage. Competetiveness Review: An International Business Journal, 23(3), 260-283.

Khalique, M., \& Pablos, P. O. (2015). Intellectual capital and performance of electrical and electronics SMEs in Malaysia. International Journal of Learning and Intellectual Capital, 12(3), 251-269.

Kianto, A., Hurmelinna-laukkanen, P., \& Ritala, P. (2010). Intellectual capital in service- and product-oriented companies. Journal of Intellectual Capital, 11(3), 305-325.

Komnenic, B., \& Pokrajcic, D. (2012). Intellectual capital and corporate performance of MNCs in Serbia. Journal of Intellectual Capital, 13(1), 106-119.

Malaysia SME Community Directory. (2013). Malaysia SME Community Directory (14th Ed.). Selangor: Empire Publishing Sdn. Bhd.

Marzo, G., \& Scarpino, E. (2016). Exploring intellectual capital management in SMEs: An in-depth Italian case study. Journal of Intellectual Capital, 17(1), 27-51.

Mayo, A. (2000). The role of employee development in the growth of intellectual capital. Personnel Review, 29(4), 521-533. 
Morariu, C. (2014). Intellectual capital performance in the case of Romanian public companies. Journal of Intellectual Capital, 15(3), 392-410.

Ngah, R., \& Ibrahim, A. R. (2009). The relationship of intellectual capital, innovation and organizational performance: A preliminary study in Malaysian SMEs. International Journal of Management Innovation Systems, 1(1), 1-13.

Omar, S. S., Arokiasamy, L. \& Ismail, M. (2009.) The background and challenges faced by the small medium enterprises. A human resource development perspective. International Journal of Business and Management, 4(10), 95-102.

Peltier, J. W. \& Naidu, G. M. (2012). Social networks across the SME organizational lifecycle. Journal of Small Business and Enterprise Development, 19(1), 56-73.

Petty, R. \& Guthrie, J. (2000). Intellectual capital literature review: Measurement, reporting and management. Journal of Intellectual Capital, 1(2), 155-176.

Saleh, A. S. \& Ndubisi, N. O. (2006). An evaluation of SME development in Malaysia. International Review of Business Research Papers, 2(1), $1-14$.

Sekaran, U. \& Bougie, R. (2010). Research methods for business: A skill building approach, $5^{\text {th }}$ Edition. West Sussex, UK: John Wiley \& Sons Lt.

Sharabati, A. A. A., Jawad, S. N., \& Bontis, N. (2010). Intellectual capital and business performance in the pharmaceutical sector of Jordan. Management Decision, 48(1), 105-131.

SMECORP. (2012). SME Annual Report 2012. SME Corporation Malaysia.

SMECORP. (2018). SME Annual Report 2015/2016. SME Corporation Malaysia. 
Ståhle, P., Ståhle, S., \& Aho, S. (2011). Value added intellectual coefficient (VAIC): A critical analysis. Journal of Intellectual Capital, 12(4),531551.

Steenkamp, N., \& Kashyap, V. (2010). Importance and contribution of intangible assets : SME managers ' perceptions. Journal of Intellectual Capital, 11(3), 368-390.

St-Pierre, J. \& Audet, J. (2011). Intangible assets and performance: Analysis on manufacturing SMEs. Journal of Intellectual Capital 12(2), 202-223.

Suraj, O. A., \& Bontis, N. (2012). Managing intellectual capital in Nigerian telecommunications companies. Journal of Intellectual Capital, 13(2), 262-282.

Sveiby, K. E. (2001). A knowledge-based theory of the firm to guide in strategy formulation. Journal of Intellectual Capital, 2(4), 344-358.

Thorpe, R., Holt, R., Macpherson, A. \& Pittaway, L. (2005). Using knowledge within small and medium-sized firms: A systematic review of the evidence. International Journal of Management Reviews, 7(4), 257-281.

Tovstiga, G., \& Tulugurova, E. (2007). Intellectual capital practices and performance in Russian enterprises. Journal of Intellectual Capital, $8(4), 695-707$.

Urbach, N. \& Ahlemann, F. (2010). Structural Equation Modeling in information systems research using Partial Least Squares. Journal of Information Technology Theory and Application, 11(2), 5-40.

Wang, Z., Wang, N., \& Liang, H. (2014). Knowledge sharing, intellectual capital and firm performance. Management Decision, 52(2), 230-258.

Wei, I. \& Ting, K. (2009). Intellectual capital performance of financial institutions in Malaysia. Journal of Intellectual Capital, 10(4), 588-599. 
Yusoff, M. N. H., \& Zainol, F. A. (2014). The public business support services: Does it really works? Asian Social Science, 10(14), 106-113.

Zainol, Z \& Ariffin, Z. Z. (2013). Difficulties in securing funding from banks: Success factors for Small and Medium Enterprises (SMEs). Journal of Advanced Management Science, 1(4), 354-357. 


\section{APPENDIX}

$\begin{array}{ll}\text { Code } & \text { Human Capital } \\ \text { HC1 } & \text { Competencies } \\ \text { KC2 } & \text { Competenteable employee } \\ \text { HC3 } & \text { Academic qualified employee } \\ \text { HC4 } & \text { Job expert employee } \\ & \text { Attitude } \\ \text { HC5 } & \text { Highly committed in completing task } \\ \text { HC6 } & \text { Willing to learn from other colleagues } \\ \text { HC7 } & \text { Motivated in their work } \\ \text { HC8 } & \text { Always share new ideas and knowledge with their colleagues } \\ & \text { Intellectual alertness } \\ \text { HC9 } & \text { Always finding new, creative and better ways to get the work done } \\ \text { HC10 } & \text { Able to bring new knowledge and innovative ideas to the company } \\ \text { HC11 } & \text { Able to predict future problems and look for opportunities to improve } \\ \text { HC12 } & \text { Capable to perform business transactions in the shortest possible time } \\ \text { Code } & \text { Structural Capital } \\ & \text { Intellectual property } \\ \text { SC1 } & \text { A good system to protect our IP } \\ \text { SC2 } & \text { Clear strategies, procedures and facilities for IP management } \\ \text { SC3 } & \text { Adequate financial allocation for the maintenance of IP } \\ & \text { Process and procedure } \\ \text { SC4 } & \text { Systematically designs and manage processes } \\ \text { SC5 } & \text { Has a clear process to evaluate and implement new ideas } \\ \text { SC6 } & \text { Has improved processes to fully satisfy and generate increasing value } \\ & \text { for stakeholders } \\ & \text { Information system } \\ \text { SC7 } & \text { Data systems that help in accessingrelevant information } \\ \text { SC8 } & \text { Up-to-date policies, procedures, networks and databases } \\ \text { SC9 } & \text { Effective information system in each department } \\ & \text { Research and development } \\ \text { SC10 } & \text { A top management that trusts and supports R\&D department } \\ \text { SC11 } & \text { Systems and procedures that support R\&D } \\ \text { SC12 } & \text { Professional and skilful employees that are necessary for R\&D } \\ \text { Code } & \text { Relational capital } \\ & \text { Customer } \\ \text { RC1 } & \text { Cares about what the customer thinks and demands from us } \\ \text { RC2 } & \text { Responds to complaints from customers in a reasonable time frame } \\ & \end{array}$


RC3 Has a good relationship with customers, which enhances the customer's loyalty

Supplier

RC4 Creates awareness among suppliers about the criteria and quality of materials supplied

RC5 Pays suppliers on time

Distribution channel

RC6 Has enough distribution channels to keep our customers satisfied

RC7 Is willing to involve the distribution channel when discussing matters that affect them

Relationship with banks

RC8 Easy to access credit from banks

RC9 Receives appropriate attention and responses from banks

RC10 Is able to supply the necessary business information required by banks

Relationship with government

RC11 Finds it is easy to access credit from agencies

RC12 The agencies are flexible when meeting changing operational needs

Financial Performance

P1 Return on assets of our company is better than competitors

P2 Return on sales of our company is better than competitors

P3 Profit growth of our company is better than competitors

P4 Sales growth of our company is better than competitors

Non-financial performance

P5 Customer satisfaction towards our company is better than competitors

P6 Productivity of our company is better than competitors

P7 Quality development of our company is better than competitors

P8 Cost management of our company is better than competitor

P9 Responsiveness of our company is better than competitors 